\title{
Phytoremediation Potential of Eichhornia crassipes(Mart.) Solms
}

\author{
Sangya S. Bais ${ }^{* 1}$, Lawrence K. ${ }^{1}$, Pandey A. K. ${ }^{2}$ \\ ${ }^{1}$ Dept. of Biochemistry and Biochemical Engineering, SHIATS, Allahabad, India \\ ${ }^{2}$ Dept. of Biochemistry, Allahabad University, Allahabad, India
}

\begin{abstract}
The present research has been carried out during rainy season, to estimate the changes in biochemical, anti-oxidative activity changes in E. crassipes along with the estimation of heavy metal content in water sample of waste water bodiespresent in trans-nearby regions of river Ganges/Yamuna in Allahabad city. The increasing oxidative stress levels caused due to heavy metal contents showed significant linear increase in antioxidant enzyme activities, i.e., catalase (CAT), peroxidase (PX), ascorbate peroxidase $(A X P)$ and superoxide dismutase (SOD) of E. crassipes root and shoot growing in polluted water and along with the analysisof chlorophyll and protein content. Oxidative stress is essentially a regulated process, the equilibrium between the oxidative and anti-oxidative capacities determine the fate of the plant. At higher pollution concentration chlorophyll and protein content of E. crassipesis slightly affected.Conclusively, the present study demonstrates that E. crassipes can tolerate higher oxidative stress andit can be used forbioremediation in polluted water. Therefore, E. crassipes is helpful in reducing the aquaticpollution andthe study provides a cost effective management to water pollution.
\end{abstract}

Keywords-Oxidative stress, antioxidant enzymes, bioremediation, aquatic pollution, peroxidase, superoxide dismutase, catalase, ascorbate peroxide.

\section{INTRODUCTION}

The toxic pollutants causing adverse effects on physical, chemical and biological factors of water bodies is known asWater pollution. It is very important to treat sewage waste water before its disposal (Sathanarayanan, 2007). Monitoring and prevention of pollution from aquatic bodies situated in public areas is one of the hot topics in environmental researches. Biological tools are being substituted as low cost alternatives in pollution abatement programs. Remediation or degradation is a technique to degrade rapidly hazardous organic contaminants to environmentally safe levels in soils, waters sludge and residues by using microorganisms, plants and animals
(Goel, 1997). Aquatic plants have the ability to remove organic and inorganic nutrients from waste water in a complete natural way known as phytoremediation (Peterson and Teal, 1996; Dhote and Savita, 2007). Now it has been shown that cost efficient methods are only possible means to recycle waste water into high quality pure water (Dipuet $a l ., 2010)$. Flora acts as an efficient accumulator of heavy metals in their body without the production of any toxicity or reduction in growth (Begum, 2009).Butaet al., 2011 has reported that E. crassipes is well known for the removal of heavy metals. The E. crassipes is considered in the research work due to their high metal removal rates of close to $100 \%$ that have been reported in both in vitro and in vivo conditions (Matagiet al., 1998).

The effects of heavy metal stress on the activity of antioxidative enzymes superoxide dismutase (SOD), peroxidase (POD) and catalase (CAT) have also been studied. The increase in enzyme activities was accompanied with higher tolerance to heavy metal stress (Sudhakaret al., 2001 and $\mathrm{Wu}$ et al., 2003). Generally, plant antioxidative enzymes are important as a plant protection mechanism against reactive oxygen species. Reactive oxygen species (ROS) inactivate enzymes and damage important cellular components. Oxidativestress is induced by a wide range of environmentalfactors. Oxygen deprivationstressin plant cells is distinguished by three physiologicallydifferent states: transient hypoxia, anoxia and re-oxygenation. Of the ROS, hydrogenperoxide $\left(\mathrm{H}_{2} \mathrm{O}_{2}\right)$ and superoxide $\left(\mathrm{O}_{2}^{-}\right)$are bothproduced in a number of cellular reactions. The formation of ROS is prevented byan antioxidant system: low molecular mass antioxidants (ascorbicacid, glutathione and tocopherols), enzymes regenerating the reducedforms of antioxidants and ROS-interacting enzymes such as SOD, peroxidases and catalases (Arora et. al., 2002). It is clear that the capacity and activity of the antioxidativedefence system are important in limiting oxidative damage and in destroying active oxygen species that are produced in excess of those normally required for metabolism(Garg,2008).Plants in the environment are 
exposed to a range of abiotic stresses like osmotic, salinity, temperature and heavy metal toxicity, which affect their growth and other physiological processes (Levitt, 1980). Both natural and man-made stress situations provoke increased production of toxic oxygen derivatives. In response, the capacity of the anti-oxidative defence system is increased. It has been E.crassipes is one of the most productive plants in the world. In addition, the increase of SOD activity in E. crassipes was in accordance with the accumulation of $\mathrm{H}_{2} \mathrm{O}_{2}$ and due to the increase of membrane peroxidation, while the activity of catalase, which might remove the excessive $\mathrm{H}_{2} \mathrm{O}_{2}$ of the E. crassipes plant parts. The oxidative stress caused due to of waste water on antioxidant enzyme activities such as superoxide dismutase, catalase and peroxidase of E. crassipeswere also investigated in the present study.

Dissolved oxygen levels as the solubility of oxygen decreases as water temperature increases. DO concentrations may be measured directly in wastewater, but the amount of oxygen potentially required by other chemicals in the wastewater is termed an oxygen demand.Both the BOD (biological oxygen demand) and COD (chemical oxygen demand) tests are a measure of the relative oxygen-depletion effect of a waste contaminant and as a measure of pollution effect. The BOD test measures the oxygen demand of biodegradable pollutants whereas the COD test measures the oxygen demand of biodegradable pollutants plus the oxygen demand of non-biodegradable oxidizable pollutants. Disposal of sewage wastes into a large volume of water could increase the biological oxygen demands to such a high level that all the available oxygen may be removed, consequently causing the death of all aerobic species, e.g., fish (Maduka, 2004). The aquatic plants showed the capacity to remove heavy metal from polluted water by accumulation in their roots via adsorption, uptake and translocation Lubberding et al., 2000; Awuah et al., 2000; Meggo, 2001 and Alick, 2002) and effective in influencing some of the physicochemical characteristics of water are dissolved oxygen (DO), biochemical oxygen demand (BOD), chemical oxygen demand (COD), electrical conductivity (EC), $\mathrm{pH}$, dissolved $\mathrm{CO}_{2}, \mathrm{HCO}_{3}$ and $\mathrm{CO}_{2}$, alkalinity, turbidity suspended solids, heavy metals etc. from waste water (Gupta, 1982; Reddy et al., 1983). Water quality analysis with reference $\mathrm{DO}, \mathrm{BOD}, \mathrm{COD}, \mathrm{pH}$, total dissolved solids (TDS), alkalinity, total hardness content were systematically, investigated determining the effective phytoremediative role of E. crassipes. Therefore, the present study was carried out in order to evaluate the aquatic macrophyte plant, 'E.crassipes' enzymatic activitychanges and heavy metal removal along with improving the quality of physico-chemical parameter present in the water bodies naturally in nearby regions of Allahabad.

\section{MATERIAL AND METHOD}

Sample area and Sampling Points(1 -6):

\section{Study area}

Allahabad is situated at $25.45^{\circ} \mathrm{N} 81.84^{\circ} \mathrm{E}$ in the southern part of Uttar Pradesh at an elevation of 98 metres $(322 \mathrm{ft}$ ) and stands at the confluence of two rivers, the Ganges and Yamuna. The region was known in antiquity as the Vats country. To its south and southeast is the Bundelkhund and regions, to its east is the mid Ganges valley of North India, or Purvanchal, to its southwest is the Bundelkhund and region, to its north and northeast is the Awadh region and to its west along with Kaushambi it forms the lower doab region.

Water samples were collected from eight samplingsites in Allahabad region inhabited with E. crassipesfor experimental analysis. Four sampling sites were from the trans-Ganges regionviz. PuraniJhusi $\left(\mathrm{S}_{1}\right)$, Daragunj $\left(\mathrm{S}_{2}\right)$,Nasirpur $\left(\mathrm{S}_{3}\right)$ while four sampling sites from the transYamuna region wereCheonki $\left(S_{4}\right)$, Maheva $\left(S_{5}\right)$, NainiGaon $\left(\mathrm{S}_{6}\right)$. Water samples from the above mentioned sites were compared against samples collected from two waste water bodies on either side of trans-Ganges and trans-Yamuna without E. crassipesgrowth and served as control ie.Daragunj and Cheonki and were designated $\operatorname{asC}_{1}$ and $\mathrm{C}_{2}$, respectively (Fig.1).The study was conducted during the rainy season (July-February 2012)

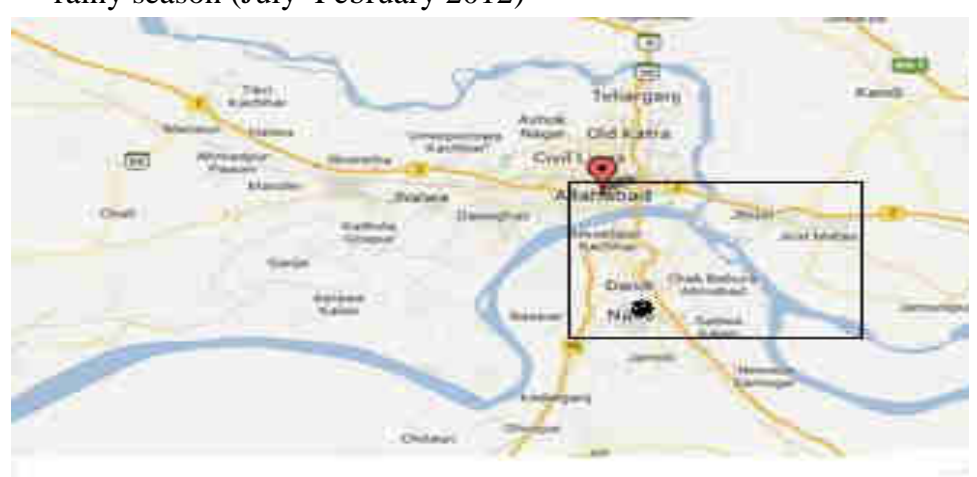

Fig. 1:Location map of the Allahabad nearby study area.

Sample collection: Wastewater samples were collected from sampling points in plastic containers previously cleaned in non-ionic detergent, rinsed with tap water and later soaked in $10 \% \mathrm{HNO}_{3}$ for 24 hours and finally rinsed with deionised water prior to usage for experimental analysis. 
Heavy metal Analysis:For sampling, the containers were thoroughly washed and rinsed with $8 \mathrm{~N} \mathrm{HNO}_{3}$ followed bydouble distilled water. Then $5 \mathrm{ml}$ conc. $\mathrm{HNO}_{3}$ per litre of sample was added at the time of collection to minimize adsorption of the metals on the container walls. For the analysis of heavy metals, 1litre of sample along with $4 \mathrm{ml}$ conc. $\mathrm{HNO}_{3}$ was evaporated in a beaker on a water bath to approximately $50 \mathrm{ml}$ and then cooled. The concentrate was transferred to $100 \mathrm{ml}$ measuring cylinder and $2 \mathrm{ml}$ conc. 1:1 $\mathrm{HCl}$ was added. The solution was make upto $100 \mathrm{ml}$ with distilled water. The acidified samples were analyzed for heavy metal (Iron; $\mathrm{Fe}^{2+}$ at248.33nm, Lead; $\mathrm{Pb}^{2+}$ at 283.31 and Chromium; $\mathrm{Cr}^{6+}$ at $357.87 \mathrm{~nm}$ ) using double-beam Perkin-Elmer AAnalyst 300 atomic absorption spectrophotometer (AAS) as per standard method of the water quality (APHA, 2002).

\section{Plant sample collection:}

The free floating E. crassipes plants were collected from the sampling sites for further biochemical and enzyme assays. The samples were labelled, stored in clean and dry polyethylene bags and transported to the laboratory. The plants were washed in running tap water blotted dry with filter paper. Damage to root and leaf apices were avoided. The samples were refrigerated at $4^{\circ} \mathrm{C}$ until used.

For the preparation of crude extracts used for the enzyme assays, $1 \mathrm{~g}$ of leaves in $10 \mathrm{ml}$ distilled water using ceramic mortar and pestle were grinded. The extract prepared was centrifuged at $15,000 \mathrm{~g}$ for $30 \mathrm{~min}$ at $4^{\circ} \mathrm{C}$ in cooling centrifuge. Filtration was made using labsman no. 1 filter paper and the filtrate utilized for enzyme analyses (De Biasiet al., 2003).

\section{Biochemical and Enzyme Assays:}

All assays were carried out at room temperature ( 22-25 $\left.{ }^{\circ} \mathrm{C}\right)$. The specificprocedure followed for each enzyme assayed is described below.

Chlorophyll estimation by Arnon(1949) and total protein estimation by Lowry et al., (1951), respectively.

Catalase(CAT) activity was measured accordingto the method of Matsumura et al.,2002) ina reaction mixture containing $1 \mathrm{ml}$ of $5 \mathrm{mMpotassium}$ phosphate ( $\mathrm{pH} 7.0), 1$ $\mathrm{ml}$ of $45 \mathrm{mMH}_{2} \mathrm{O}_{2}$ and $1 \mathrm{ml}$ of the crude extract. The activitywas determined by the decrease of absorbanceat 240 $\mathrm{nm}$ due to $\mathrm{H}_{2} \mathrm{O}_{2}$ consumptionusing Corning 258 spectrophotometer. Oneunit was defined as $1 \mathrm{mM}$ of $\mathrm{H}_{2} \mathrm{O}_{2}$ decomposedper minute and the activity referred tomilligrams of protein. Protein was determinedin extract according to the method describedby Bradford (1976).

Peroxidase (POD) activity was determined accordingto the method of Chanda and Singh (1997).The reaction mixture contained $1 \mathrm{ml}$ of the leafextract, $1 \mathrm{ml}$ of $1 \mathrm{mM} \mathrm{H}_{2} \mathrm{O}_{2}, 1 \mathrm{ml}$ of 4 mMguaiacol and $1 \mathrm{ml} \quad 8 \quad \mathrm{mM}$ potassium phosphatebuffer ( $\mathrm{pH}$ 6.5). The change in absorbance at 470 $\mathrm{nm}$ due to the oxidation of guaiacol to formtetraguaiacol in the presence of $\mathrm{H}_{2} \mathrm{O}_{2}$ was measured.The Peroxidase activity was expressedas the rate of change of optical density (OD)per minute.

Superoxide dismutase (SOD) activity was measuredas described by Calatayudet al., (2002).The reaction mixture contained $1 \mathrm{ml}$ each of $50 \mathrm{mM}$ potassium phosphate buffer ( $\mathrm{pH}$ 7.8),10 $\mathrm{mM}$ methionine, $57 \mu$ Mnitroblue tetrazolium(NBT), $1.0 \mu \mathrm{M}$ riboflavin, $0.025 \%$ (v/v)Triton $\mathrm{X}-100$ and crude extract. The mixturewas thoroughly shaken and illuminated for $5 \mathrm{~min}$ with 60 Watt electric bulb placed 20 cmaway. Absorbance was recorded at $560 \mathrm{~nm}$ afterthe illumination period. In this assay, 1 unit ofSOD was defined as the amount of enzymenecessary to produce a 50 $\%$ inhibition of the NBT photoreduction.

Polyphenol Oxidase(PPO)activity was estimated simultaneously by themethod of Esterbaueret al. (1977) and estimated spectrophotometrically at $495 \mathrm{~nm}$. The $2.5 \mathrm{ml}$ of Phosphate buffer(0.1M,pH 6.5) and $0.3 \mathrm{ml}$ of catechol $(0.01 \mathrm{M})$ solution were added in the cuvetteand the spectrophotometer was set at $495 \mathrm{~nm}$. The $0.2 \mathrm{ml}$ of enzyme extract was added andthe change in absorbance was recorded for every 30 seconds up to 5 minutes in aspectrophotometer at $495 \mathrm{~nm}$. One unit of catechol oxidase is defined as the amount of enzyme thattransforms $1 \mu$ mole of dihydrophenol to $1 \mu$ mole of quinone per minute.

Statistical Analysis: Each treatment was analyzed with a minimum of 3 replicates and the Standard Deviation (SD) was calculated. All the data reported as MEAN $\pm \mathrm{SD}$ (Minimum of 3 replicates).

\section{RESULTS}

The present research has been carried out in the period of July 2011 to February 2012.E.crassipesof the water samples collected from sampling points were the average temperature recorded between $25.5^{\circ} \mathrm{C}$ to $35.6^{\circ} \mathrm{C}$ with following inferences.

Heavy Metal Removal-Generally, heavy metals present and the oxidative stress on the E. crassipes in waste water bodies increases the activities of the antioxidant enzymes investigated, and the increase was proportional to pollutant level of water bodies. The results of heavy metal $\left(\mathrm{Fe}^{2+}\right.$, $\mathrm{Cr}^{6+}$ and $\mathrm{Pb}^{2+}$ ) reduction levels due to water hyacinth (shoots and roots) presence were analyzed and were compared with the control without E. crassipesin the sampling areas are given in presented in Fig.2. 


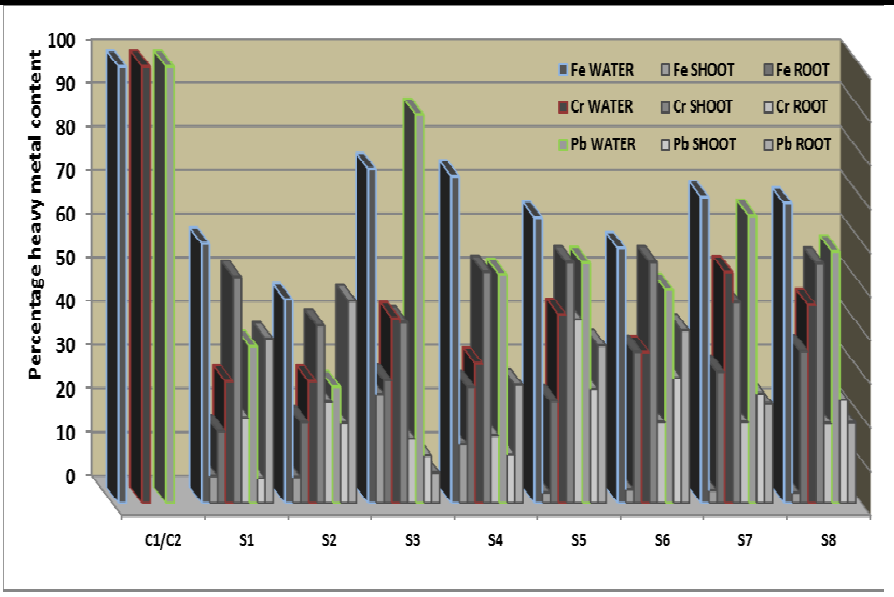

Fig.2: Comparison between the heavy metals content $\left(\mathrm{Fe}^{2+}\right.$, $\mathrm{Pb}^{2+}$ and $\mathrm{Cr}^{6+}$ ) accumulation in E.crassipes (shoots and roots) of Allahabad sampling sites during rainy season.

From the present study, the order of decrease of $\mathrm{Cr}^{6+}$ content in water sample from trans-Gangessites was $72 \%$ $\left(\mathrm{S}_{2}\right.$ and $\left.\mathrm{S}_{1}\right)>58 \%\left(\mathrm{~S}_{3}\right)$ as compared to $\mathrm{C}_{1}$. From transYamuna sites, the decrease was in order of $83 \%\left(\mathrm{~S}_{5}\right)>80 \%$ $\left(\mathrm{S}_{4}\right), 35 \%\left(\mathrm{~S}_{6}\right)$ over the control $\left(\mathrm{C}_{2}\right)$ water sample. The order of decrease in $\mathrm{Fe}^{3+}$ content from trans-Gangessites was $53 \%$ $\left(\mathrm{S}_{2}\right)>41 \%\left(\mathrm{~S}_{1}\right)>23 \%\left(\mathrm{~S}_{3}\right)$ as compared to $\mathrm{C}_{1}$ while, from trans-Yamuna sites, decrease was $67 \%\left(\mathrm{~S}_{6}\right)>50 \%$ $\left(\mathrm{S}_{5}\right)>38 \% \quad\left(\mathrm{~S}_{8}\right)>20 \% \quad\left(\mathrm{~S}_{7}\right)$ over the control $\left(\mathrm{C}_{2}\right)$ water sample. The order of decrease in $\mathrm{Pb}^{2+}$ content from transGangessites was $73 \%\left(\mathrm{~S}_{2}\right)>63 \%\left(\mathrm{~S}_{1}\right)>11 \%\left(\mathrm{~S}_{3}\right)$ as compared to $\mathrm{C}_{1}$. From trans-Yamuna sites, the decrease was $72 \%$ $\left(\mathrm{S}_{5}\right)>61 \%\left(\mathrm{~S}_{4}\right)>35 \%\left(\mathrm{~S}_{6}\right)$ over the control $\left(\mathrm{C}_{2}\right)$ water sample. From trans-Ganges/Yamuna sampling sites, $\mathrm{S}_{2}(72 \%)$ and $\mathrm{S}_{5}(72 \%)$ highest $\mathrm{Pb}^{2+}$ accumulation; $\mathrm{S}_{1}(71 \%)$ and $\mathrm{S}_{5}(79 \%)$ highest $\mathrm{Cr}^{6+}$ accumulation and $\mathrm{S}_{2}(52 \%)$ and $\mathrm{S}_{5}(66 \%)$ highest $\mathrm{Fe}^{3+}$ accumulation in E. crassipes (shoots + roots). The pattern of the sites having highest heavy metal accumulation in the plant was $\mathrm{Pb}^{2+}>\mathrm{Cr}^{6+}>\mathrm{Fe}^{3+}$ mostly in $\mathrm{S}_{2}$ and $\mathrm{S}_{5}$ sites from the trans-Ganges/Yamuna sampling sites of Allahabad (fig.2).

The present study is in agreement with the findings of Mahmood et .al.,(2005) who concluded that E. crassipeshas tremendous potential to absorb heavy metals from the textile wastewater which resulted in a $94.78 \%$ reduction in $\mathrm{Cr}^{6+}$ and $96.88 \%$ in $\mathrm{Zn}^{2+}$ due to an extensive adventitious root system, which offers more surface area for absorption. The results of Lissyet.al.,(2010) demonstrated 65\% removal of $\mathrm{Cr}^{6+}$ and $\mathrm{Cu}^{2+}$ contents from the waste water achieved by water hyacinth in respect to the control which is without $E$. crassipes. From the study of Gakwavuet al., (2009), $\mathrm{Zn}^{2+}$ was accumulated was about $56.7 \%$ in petioles $>27.0 \%$ in leaves $>16.3 \%$ in roots and for $\mathrm{Cr}^{6+}$ content was $73.7 \%$ in roots $>14.1 \%$ in petioles $>12.2 \%$ in leaves by water hyacinth plants. The results of present study in tune with the observation of Maria et al., (2001) were $72 \%$ of $\mathrm{Cd}^{2+}$ content was removed by water hyacinth during experimental period while, $90 \%$ of $\mathrm{Cd}^{2+}$ and $\mathrm{Zn}^{2+}$ content was removed according to the study of Mishra and Tripathi (2008). Ritusmitaet al., (2010) reported that more than $90 \%$ of lead was removed by water hyacinth. Brix (1993) observed that E. crassipeshas been used successfully in wastewater treatment system to improve the water quality by reducing the levels of organic and inorganic pollutants. In conclusion, water hyacinth

Biochemical assay:

From the study, maximum increase of total chlorophyll was observed in $\mathrm{S}_{2}$ and in $\mathrm{S}_{5}$ compared between the respective trans-Ganges/Yamuna sampling sites of E. crassipes(Fig.3). Maximum increase of $24 \%$ in chl. a, $11 \%$ in chl. b and by $16 \%$ in total chlorophyll was observed in $\mathrm{S}_{2}$ compared between the trans-Ganges sampling sites while, maximum increase observed was $36 \%$ in chl. a, $7 \%$ in chl. b and $21 \%$ total chlorophyll in $\mathrm{S}_{5}$ compared between the transYamuna sampling sites of E. crassipes. In comparison with both trans-Ganges/Yamuna sampling sites, the maximum percentage increase observed was $23 \%$ in chl. a, $12 \%$ in chl. b and $22 \%$ in total chlorophyll observed in trans-Yamuna site i.e., in $\mathrm{S}_{5}$.

Similarly, the study reports maximum protein content in $E$. crassipes was reported $13 \%\left(\mathrm{~S}_{3}\right)$ in shoot and $10 \%\left(\mathrm{~S}_{2}\right)$ in root from trans-Ganges sites, while from trans-Yamuna sampling sites maximum increase was $11 \%\left(\mathrm{~S}_{2}\right)$ in shoot and $10 \%\left(\mathrm{~S}_{5}\right)$ in root compared between transGanges/Yamuna sites, respectively. From the comparison between both the trans-Ganges/Yamuna sampling sites, the highest increase was observed $14 \%\left(\mathrm{~S}_{4}\right)$ in shoot and $2.3 \%$ $\left(\mathrm{S}_{5}\right)$ in root protein content of E. crassipes (Fig.4).

The presence of pollutants in water bodies has a negative effect on biochemical aspects of plant life. The presence of pollutants in water bodies has a negative effect on biochemical aspects of plant life. Many deleterious environmental influences that inhibit plant growth, ranging from nutrient deficiencies to anthropogenic pollution, can result in decreased leaf chlorophyll contents (Borkeret. al., 2013). The present study is in agreement with the findings of Chen and Djuric, 2001 who stated that chlorophyll degradation is the routinely observed response to stress or chiefly in elevated concentrations of various heavy metals. Mohan and Hosetti (1997) found more pronounced decrease 
in the protein content with $\mathrm{Cd}^{2+}$ as compared to $\mathrm{Pb}^{2+}$ treatment in L. minor.Borkeret al., (2011) reported that the effect of $\mathrm{ZnCl}_{2}$ on chlorophyll content of mature leaves of E. crassipesit is evident from the results that the total chlorophyll content of the mature leaves slightly decreased at $75 \mathrm{ppm}(0.80 \%)$ as compared to the control. The results on reduced levels of chlorophyll pigments at higher levels of metal salt are in consistent with the findings of Mishra $e t$ al. (2007). Similarly, a heavy metal concentration dependent reduction in chlorophyll content over control was also observed in the leaves of L.esculentum(Gaubaet al., 2007). Several cases of decreased chlorophyll content owing to metal toxicity have been reported in the plant kingdom growing in wetland ecosystems (Valavanidiset al., 2005). In the present study, the aim to evaluatewater hyacinth fitting strategies towards undesirable environmental conditions.

Odjegba and Fasidi(2004) study on the E.crassipesand $P$. stratiotes implication in the phytoremediation of waters polluted with low levels of heavy metals and to determine whether part of the differences in stress tolerance between $E$. crassipesand $P$. stratiotes could be explained by differences in reactive oxygen metabolism. It was reported that the nonlethal concentrations of heavy metalswould cause increased oxidative stress and therefore induce defence systems against ROS and that the effects of the metals would be different while the species with overall higher levels of antioxidant enzyme activity would comparatively tolerate heavy metal stress more than the other species.

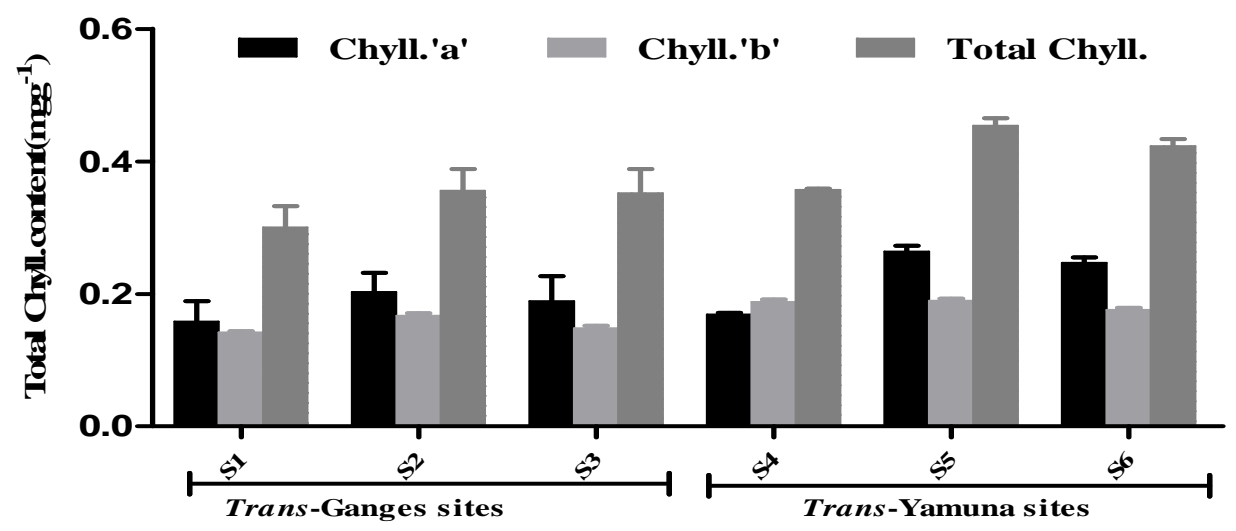

Fig. 3: Total chlorophyll content $\left(\mathrm{mgg}^{-1} \mathrm{FW}\right)$ of E. crassipes presents in trans-Ganges/Yamuna sites.

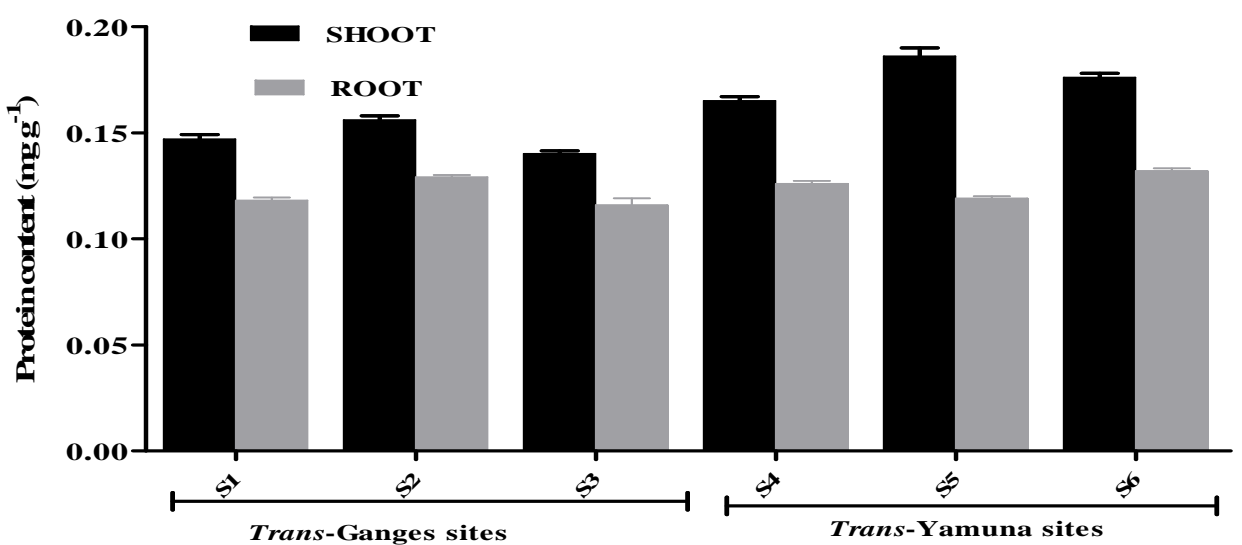

Fig.4: Comparison of protein content ( $\left.\mathrm{mgg}^{-1} \mathrm{FW}\right)$ in E. crassipes (shoots and roots).

Anti-oxidant enzymes:Oxidative stress is essentially a regulated process, the equilibrium between the oxidative and anti-oxidative capacities determine the fate of the plant. From the study, all the sampling stations significant activity 
is observed to be higher activity in root than in shoot of E.crassipes.

From the study, it was observed to have significant changes in the antioxidant enzyme activity of the shoot and root parts of E. crassipes present in waste water bodies of the sampling sites. It was reported that in maximum increase in enzymatic activity in E. crassipes (in shoots and roots) was mostly found in $\mathbf{S}_{\mathbf{2}}$ and $\mathbf{S}_{\mathbf{5}}$ sites from sampling sites. The maximum catalytic specific activity $\left(\mathrm{U} \mathrm{mg}^{-1}\right.$ protein) in shoots of the E . crassipes was observed maximum in $\mathrm{S}_{2}$ (35) and in $S_{5}$ (40) while was observed maximum in $S_{2}$ (93.5) and $\mathrm{S}_{5}$ (76.4) in roots (fig.5);SOD specific activity ( $\mathrm{U} \mathrm{mg}^{-1}$ protein) was observed maximum in $\mathrm{S}_{2}(4.8 \mathrm{U})$ and in $\mathrm{S}_{5}(4.4)$ in shoots of the E. crassipes along with same pattern in roots of the E. crassipesi.e, $\mathrm{S}_{2}(4.73)$ and $\mathrm{S}_{5}$ (6.48) (fig.8); maximum guaiacol peroxidase specific activity $\left(\mathrm{U} \mathrm{mg}^{-1}\right.$ protein) was observed in $S_{2}$ (175.08) and in $S_{6}$ (175.08) observedin shoots and in roots observed maximum in $S_{2}$ (662.0) and in $\mathrm{S}_{5}$ (760)(fig.6). Similar pattern of maximum increase was observed in the PPO specific activity $\left(\mathrm{U} \mathrm{mg}^{-1}\right.$ protein) i.e., in $\mathrm{S}_{2}(0.16)$ and in $\mathrm{S}_{5}(0.0044)$ in shoots while, in roots was observed in $S_{2}(0.0219)$ and $S_{5}(0.0126)$ (fig.7)of the $E$. crassipes present in the sampling sites.

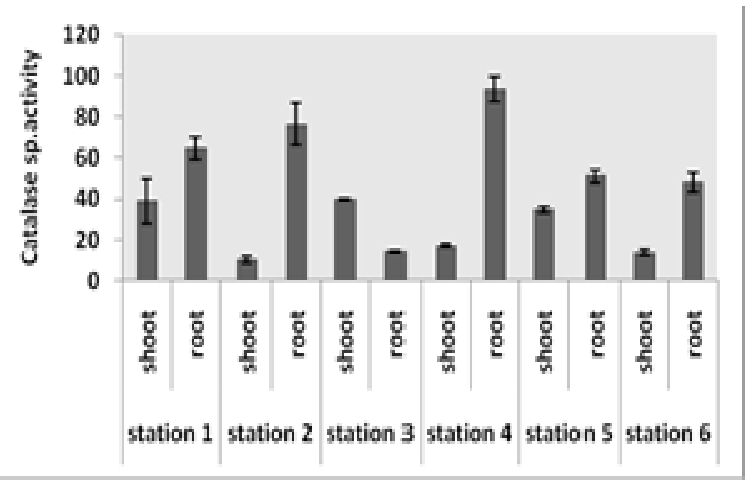

Fig.5:CAT activity ( $\mu \mathrm{mol}$ mg-1 protein) E. crassipes.

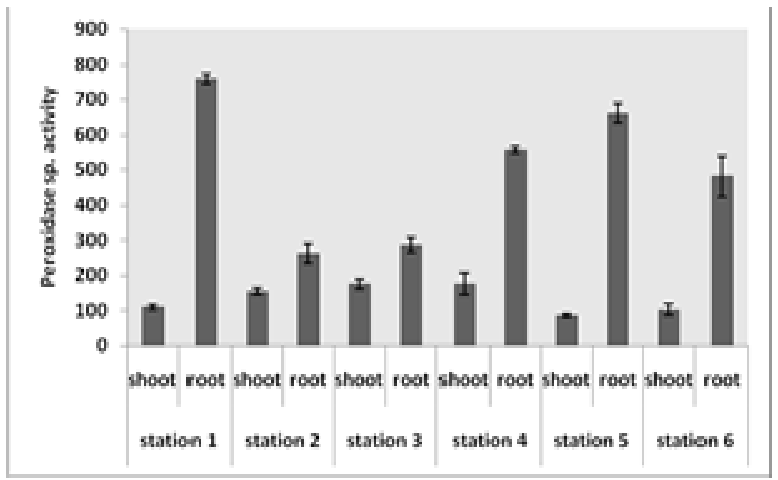

Fig.6:GPX activity $\left(\triangle_{470} \mathrm{~min}^{-1} \mathrm{~g}^{-1} \mathrm{FW}\right)$ of E. crassipes

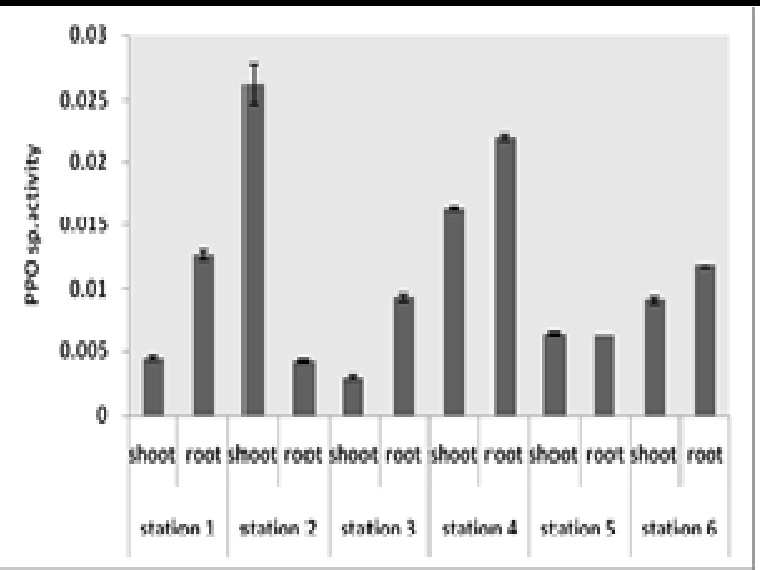

Fig.7:PPO sp. activity ( $\mathrm{Umg}^{-1}$ protein) of E. crassipes.

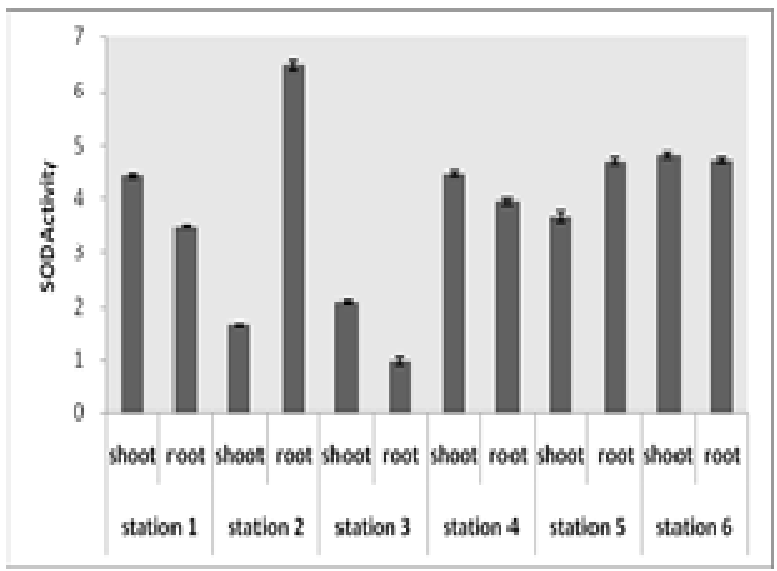

Fig.8:SOD activity (Umg ${ }^{-1}$ protein) of E. crassipes. (All experiments performed in triplicates $n=3$ and are shown in Means and standard deviation)

It was reported that enzymatic activities was found increased in roots than in shoots of E.crasspes. The increased enzymatic activities in shoots and roots of E.crasspes was likely to protect plants from heavy metal induced oxidative stress by activating multi defense mechanisms and for better growth in polluted environments. SODacts as the first line of defence against ROS, dismutating superoxide to $\mathrm{H}_{2} \mathrm{O}_{2}$ and APX, GPX and CAT and subsequently detoxifying $\mathrm{H}_{2} \mathrm{O}_{2}$. Among various enzymatic enzymes involved in the abolishment of ROS, SOD plays a pivotal role, it reduces the oxidative stress by dismutation of two superoxide radicals to $\mathrm{H}_{2} \mathrm{O}_{2}$ and $\mathrm{O}_{2}$ (Cakmak, 2000). CAT present in peroxisomes and mitochondria decomposes $\mathrm{H}_{2} \mathrm{O}_{2}$ to water and oxygen. POD consumes $\mathrm{H}_{2} \mathrm{O}_{2}$ to generate phenoxy compounds that are polymerized to produce cell wall components such as lignin (Singh et al, 2006; Gupta et al, 2011). 
The present study is in agreement with the findings of Borker (2011) who stated that the activity of catalase was increased $(+119.71 \%)$ in the leaves of Eichhorniaby at 75 ppm $\mathrm{ZnCl}_{2}$ over the control. The increase in catalase under the influence of zinc chloride might be associated with the detoxification mechanism which indicates the relationship between metal tolerance and antioxidant defense system. Similarly induction in the catalase activity by $E$. crassipesin the presence of heavy metals has been reported earlier (Odjegba and Fasidi, 2007). The present study is in agreement with the findings of Srinivasan (2014) who stated that the catalase activity increases by $60 \%$ and $177 \%$; APX activity increases by $537 \%$ and $55 \%$ and POX activity increased about $589 \%$ and $254 \%$ in leaf and root tissues, respectively as compared to the control without $\mathrm{Pb}^{2+}$ treatment. Krishna et al., (2012), the antioxidant potential of Amorphophalluscommutatusintuber exhibited significant SOD (47.7 $\pm 5.5 \mathrm{U} / \mathrm{g}$ tissue), AAO $(0.38 \pm 0.12 \mathrm{U} / \mathrm{g}$ tissue), PPO $(0.8 \pm 0.45 \mathrm{U} / \mathrm{g}$ tissue) while young leaves contained significant CAT (64.3 $\pm 6.02 \mathrm{U} / \mathrm{g}$ tissue). Generally, heavy metals increased theactivities of the antioxidant enzymes investigated, and the increase was proportional to heavy metal. However, there was adifferential level of inducement among various metalsand this had a direct relationship with the toleranceof the metal by the plant species. Oxidative stress is essentially a regulated process, the equilibrium between the oxidative and anti-oxidative capacities determine the fate of the plant. At higher pollution concentration chlorophyll content of $E$. crassipesis slightly affected. Armed with a better understanding of this symbiotic association, this environment friendly system can be fruitfully employed in the field of phytoremediation. Wetland plants are being used successfully for the phytoremediation of pollutants in natural and constructed wetlands. The high productivity and resilience of the weed make them ideal macrophyte for wastewater treatment (Xiaomeiet al., 2004).

\section{CONCLUSIONS}

E. crassipesis suitable for wastewater treatment. This luxuriant plant has the tremendous capacity for absorbing toxic heavy metals and other pollutants from wastewater showing its phyto-remediation potential.Overall study reported that total chlorophyll was and protein content in $E$. crassipes was found to be lower in sites from trans-Ganges than the trans-Yamuna regions due to the higher pollutant stress. Summarizing the present study results, it is observed that enhanced antioxidant level especially in stressed plants of E. crassipesmay account for its better survival in contaminated water bodies and while higher level of pollutants decreased antioxidant activities dramatically showing reduced metal tolerance capacity and overall inhibition of plant growth.Eichhorniacrassipesis invokes considerable interest in developing cost effective and environmentally friendly technologies used in improving the effluent quality of the municipal, agricultural and industrial wastewaters bynot onlyremoving pollutants from the water, but also alters the physicochemical characteristics of the water.

Acknowledgements: The present study has been carried out in the Dept. of Biochemistry and Biochemical Engineering and Dept. of Environmental and Soil Sciences of SHIATS, Allahabad.

\section{REFERENCES}

[1] APHA(2002).Standard Methods for the Examination of Water and Wastewater, American Public Health Association, AWWA, and WPCF, Washington DC.

[2] Arora A. Sairam R. K., Srivastava G. C. (2002). Oxidative stress and antioxidant system in plants. Curr. Sci., 80(10):1221-1235.

[3] Asa F, Maria G. 2003. Aquatic and Terrestrial Plant species with potential to remove heavy metals from storm water. International Journal of phytoremediation; 5(3): 211-224.

[4] Begum A. 2009. Concurrent removal and accumulation of Iron, Cadmium and Cupper from waste water using aquatic macrophytes. Der Pharma Chemica. 1(1): 219-224.

[5] Borker A. R., Mane A.V., Borker T. M., Pathade G. R., Saratale G. D.(2011). Study of Zinc Chloride induced changes in biochemical and water quality parameters with reference to Eichhorniacrassipes. Int. J. of Environmental Sciences, 2, pp.2.

[6] Bradford, M.M. 1976. A rapid and sensitive method for the quantification of microgram quantities of protein, utilizing the principle of protein-dye binding. Anal. Biochem. 72: 248-254.

[7] Calatayud, A., J.W. Ramirez, D.J. Iglesias \& E. Barreno. 2002. Effects of ozone on photosynthetic CO2 exchange, chlorophyll a fluorescence and antioxidant system in lettuce leaves. Physiol. Plant. 116: 308-316.

[8] Chanda, S.V. \& Y.D. Singh. 1997. Changes in peroxidase and IAA oxidase activities during wheat grain development. Plant Physiol. Biochem. 35: 245250 . 
[9] Cheng S. (2003). Heavy metals in plants and phytoremediation. Environmental Science and Pollution Research, 10: 335-340

[10] De Biasi, M.G., S. Astolfi, A. Acampora, S. Zuchi, V. Fonzo, E. Satangelo, R. Caccia, M. Badiani\& G.P. Soressi. 2003. A H2O2-forming peroxidase rather than a $\mathrm{NAD}(\mathrm{P}) \mathrm{H}$-dependent $\mathrm{O} 2$ - synthase may be the major player in cell death responses controlled by the pto-Fen complex following fenthion treatment. Funct. Plant Biol. 30: 409-417.

[11] Dhote S, Savita D. 2007. Water Quality Improvement through Macrophytes: A Case Study. Asian J Exp Sci., 21(2): 427-430.

[12] Dipu S, Anju A, Kumar V, Thanga SG. 2010. Phytoremediation of Dairy Effluent by Constructed Wetland Technology Using Wetland Macrophytes Global Journal of Environmental Research, 4 (2): 90100.

[13] Garg (2008). Water pollution and plants.Arch. Biochem. Biophys., 30, pp. 222-225.

[14] Goel P. K. 1997. Water pollution, causes, effects and control. New Age International (P) Ltd. Publishers, New Delhi. pp 269.

[15] Keskinkan O, Goksu MZL, Basibuyuk M, Forster CF. 2004. Heavy metal adsorption 802 properties of a submerged aquatic plant (Ceratophyllumdemersum). Bioresou Technol. 803 (92): 197-200.

[16] Krishna. Krishna Kumari and Schandrakala (2011).Evaluation of antioxidant properties of different parts of Amorphophalluscommutatus, an endemic aroid of western ghats, South India. International Journal of Pharma and Bio Sciences, 3(3), pp.443 455. ISSN 0975-6299

[17] Lissy P. N. A., Madhu B. G. (2010).Removal of heavy metals from waste water using water hyacinth. Proc. of Int. Conf. on Advances in Civil Engineering.,42- 47.

[18] Matagi SV, Swai D, Mugabe R. 1998. A review of heavy metal removal mechanisms in wetlands. African J Trop Hydrobiol. 8: 23-25.

[19] Matsumura, T., Tabayashi N., Kamagata Y., Souma C. and Saruyama H. (2002). Wheat catalase expressed in transgenic rice can improve tolerance against low temperature stress. Physiol. Plant., 116, pp. 317-327.

[20] Mohan B.S., Hosetti B.B. (1997): Potential phytotoxicity of lead and cadmUm to Lemna minor L. growth in sewage stabilization ponds. Environ. Pollut.,98, pp. 233-236.

[21] Mishra V. K., Upadhyay A. R., Pandey S. K., Tripathi B. D. (2008). Concentrations of heavy metals and aquatic macrophytes of GovindBallabh Pant Sagar an anthropogenic lake affected by coal mining effluent. Environmental Monitoring and Assessment, 141, pp.49-58.

[22] Nadebaum P. (Eds.). Managing Arsenic in the Environment: From Soil to Human Health. CSIRO, Collingwood, Victoria, pp. 235-247.

[23] Odjegba V. J., Fasidi I. O. (2007). Changes in antioxidant enzyme activities in E.crassipes(Pontederiaceae) and Pistia stratiotes (Araceae) under heavy metal stress. Int. J. Trop. Biol.; (ISSN-0034-7744), 55 (3-4), pp. 815-823.

[24] Peterson SB, Teal MJ. 1996. The role of plants in ecologically engineered waste water treatment systems. Ecological Eng. 6(13):137-148.

[25] Robinson B, Marchetti M, Moni C, Schroeter L, van den Dijssel C, Milne G, Bolan N, Mahimairaja S. 2005. Arsenic accumulation by aquatic and terrestrial plants. in Naidu R, Smith E, Owens G, Bhattacharya P, Sathanarayanan U. 2007. Textbook of Biotechnology. Books and Allied (P) Ltd., Kolkata. pp. 667-707.

[26] Sudhakar, C., A. Lakshmi and Giridarakumar, S. (2001) Changes in the antioxidant enzyme efficiency in two high yielding genotypes of mulberry (Morusalba L.) under $\mathrm{NaCl}$ salinity. Plant Sci. 161, 613-619.

[27] Wu, P., Ma, L., Hou, X., Wang, M., Wu, Y., Liu, F. and Deng, X.W. (2003) Phosphate starvation triggers distinct alterations of genome expression in Arabidopsis roots and leaves. Plant Pysiol. 132, 12601271. 